\title{
Impact of Market Orientation Practice on Business Performance of Airline Operators in Nigeria.
}

\author{
Udegbe, Scholastica Ebarefimia \\ Department of Marketing, Lagos State University, Ojo, Lagos, Nigeria
}

\begin{abstract}
In today's global market, business are faced with intensive competition and challenges, and research have shown that through proper market orientation practice some challenges of sustainable and human development can be addressed, while also providing added value to firm. Hence this study investigates the impact of market orientation practices on business performance of airline operators in Nigeria. A survey research design was adopted and research was based on convenience sampling method. Copies of questionnaire were administered to 400 respondents from selected staff of airline operators in Nigeria, and 359 useable questionnaires were returned (i.e. $89.75 \%$ ). The data collected were analyzed using descriptive statistics and regression analysis. Validity and reliability test indicate that all variables were valid and reliable. Based on the data analysis, the findings revealed that majority of the respondents scored the issues raised in the questionnaire positively, but at different varied levels. However, it is found that market orientation marketing strategy is practiced to a reasonable extent, and vigorously integrated into the activities of airline operators in Nigeria because of its benefits. Feedback from the research will assist to expand knowledge as to the usefulness and practice of market orientation.
\end{abstract}

Keywords: Market Orientation (MO), Airline operators, Performance, Nigeria.

\section{Introduction}

Market orientation has occupied the centre stage of the theory and practice of marketing strategy, and is becoming one of the hottest academic and practical topics in the business field. In fact, due to the competitive environment, market orientation is crucial and has become the niche for firm's performance. However, there is limited research that reveals the relationship between MO practices and airline operators performance in developing country like Nigeria. The world Bank and United Nations Environment programs have shown that sustainable and human developments are closely linked to easy access to innovation, technology and services . In most developing economies, the lack of infrastructure to support services has contributed to airline operators problems in Nigeria. From research, it has been observed that lack of adequate reliable infrastructure and irregular power supplies is one of the biggest disincentives to innovation and investment in Nigeria. This has resulted to diminishing and lack of rapid economic growth in Nigeria. Despite Nigeria huge resources, it ranks one of the lowest provider of infrastructure and airline services globally . Based on above observation, It is possible that the problem might not necessarily be infrastructural problem alone, but rather airline operators problem as well.. Hence, the need for this study, bearing in mind that market orientation has occupied the centre stage of the theory and practices of marketing strategy, and has focused on the vital concepts for successful business performance, regardless of the market turbulence, completion, or technological turbulences of the environment in which the business operate (Jaworski and Kohli 1993; Slater and Narver 1995). Hence, it is worth assessing whether market orientation practices is being practiced, and to investigate if it is beneficial to the business performance of airline operators in Nigeria.

The paper starts with a critical look at the current literature on market orientation practices, and goes on to formulate hypotheses based on key constructs of finding the level of emphasis on market orientation practices, and its impact on business performance of airline firms operating in Nigeria environment.

The major objective of this research is to provide knowledge regarding the effectiveness of market orientation practices of airline firms operating in Nigeria, and its significance to performance. The following hypothesis slated in the null form were formulated and tested in order to achieve the objectives of the study:

H1o: The greater senior management emphasis on customer intelligence generation, intelligence dissemination and intelligence responsiveness of the airline services in Nigeria, the lower the market orientation practice.

H2o: The greater the top management risk aversion, the lower the market orientation practices.

H3o: the greater the interdepartmental conflict, the lower the customer emphasis, market intelligence dissemination and responsiveness of the airline operators' services in Nigeria.

H40: the greater the interdepartmental connectedness, the lower the customer emphasis, intelligence generation, market intelligence dissemination and responsiveness of the airline operators services in Nigeria.

H5o: The greater the formalization in decision making, the lower the intelligence dissemination, and responsiveness. 
Impact of Market Orientation Practice on Business Performance of Airline Operators in Nigeria.

H60: The greater the centralization in decision making, the lower the market orientation.

H7o: The greater the reliance on customer satisfaction and performance as a measure for rewarding manager, the lower the customer emphasis market intelligence dissemination and responsiveness of the airline firms in Nigeria.

H80: The greater the market orientation practices of airline operators firms in Nigeria, the lower the firm business performance (profitable market share, customer satisfaction, repeat customer, innovation, and sales growth,).

The hypotheses proposed in this paper integrate theories and constructs from extant literature on market orientation strategy ( Kohli and Jaworski 1990, 1993; Slater and Narver 1990, 1994, 1995 ; Lafferty and Huit 2001 ; Shapiro 1998; Ruekert 1992; Lado et al 1998 ; Tomaz 2005 ; and among other,) to incorporate both individual, social and infrastructural perspectives on airline operators firms performance in Nigeria. This study will not only find out the relationship between market orientations practices, with evidence from airline operators firms in Nigeria but also add to the previous literature.

\section{Literature Review}

Since the beginning of the 90's the concept of market orientation has attracted immense attention from marketing scholars and academics. This is not surprising because, it is closely related to fundamentals of marketing theory, which is marketing concept (Kotler 2002). With the implementation of market orientation activities, many companies have pursued to enhance their performance and effectiveness in search of achieving differentiation in the market. Kohli and Jaworki (1990) and Naver and Slater (1990) are often cited as founders of conceptualization and measurement instruments for assessing market orientation construct. In recent years however, improvements or alternative approaches have been suggested by different authors (Deng and Dart (1994), Lado et al, (1998), Gray et al (1998), Lafferty and Hult (2001), Vargo and Lusch, 2004, Gorenroos (2000), Loing et al (2002), Tomaz (2005) ; Bigne et al (2003) ; Ellis (2006) ; Ramayah et al (2011 ; and among others .).

Kohli and Jaworski (1990) defines market orientation as the organisation wide generation of market intelligence pertaining to current and future needs of customers, dissemination of intelligence within an organisation and responsiveness to it. Narver and Slater (1990), defined market orientation as the organisational culture that most effectively and efficiently crates the necessary behaviours for the creation of superior value for buyers and thus superior performance for business. These authors define three basic components of the construct as: customer orientation, competitor orientation and inter-functional co-ordination. To the three basic components they also added two decision criteria, long-term focus and profitability.

However, Deshpande, Farley and Webster (1993) challenged both conceptions. They see market orientation as being distinguishable from competitor orientation. They posit that putting customer interest first should be the main focus of market orientation. They argue that competitor orientation can be almost antithetical to customer orientation when the focus is more on the strength of competitors than on the unmet needs of the customer. Marketing orientation may be seen as a model of service marketing. Tomaz (2005) purposed model which consist of six dimensions: Strategic Deployment, Internal Integration, Market Knowledge Management, Organisational Infrastructure, Customer Interface design and Organisational Culture. With respect to this proposed dimensions, the present research provides fact - based evidence on the incidence of market orientation practices by airline firms operating in a developing economy (Nigeria) and it also help to judge and classify the responding airline firms according to their level of market orientation practices. Gray et al. (1990) proposed a five factor instrument which combines the Kohli and Jaworski (1990) and Narver and Slater (1990) dimensions. The dimensions of their instrument are inter-functional co-ordination, profit emphasis, competitor orientation, customer orientation, and responsiveness. Lado et al. (1998) added distributor orientation and environmental orientation models which encompass two stages of the market orientation process analysis.

To operationalize market orientation process, one should start with thorough analysis of the company and its environment, the market on which it operates, competition, customer demands and expectation and satisfaction level of customers, employees and among others ( Blackson and Stokes ,2002 ; Maydeu-Olivares and Lado 2003 ;Raaij, Stoelhorst 2008 ; Hult Ketchen 2000;. According to Kohli and Jaworski (1990). Marketing theorist have provided a number of simple tools such as SWOT (i.e. analysis of strength, weaknesses, opportunities and threat ). The concept of business performance has a variety of meanings. Firm performance is the comparison of the value which a firm creates with the value an owner expects to receive from the firm. Previous researchers have measured performance in terms of operating efficiencies, profitability, financial returns, presence in international market, export share, innovation, and new product development (Jaworski \& Kohli, 1993; Narver \& Slater 1990; Ramayah et al; and among others). 


\section{Research Methods}

The study is a survey that used both primary and secondary data. Primary data were obtained with the aid of standardised instrument (questionnaires) while the secondary data were obtained from extant literature. A convenience sample of 400 respondents working in the various airline firms ( e.g., KLM , British Airways ,Virgin Atlantic, Lufthansa, Qatar airline „, Egypt airline, Arik airline, Peace airline, Air France . Emirate airline, Delta airline, Ghana airline, and among others) operating in Nigeria were taken. Questionnaires with instructions were hand-delivered to respondents. Confidentiality was assured and incentive for participating in the research by making the report of the research available to the respondents if they so desire was promised. 400 questionnaires were distributed to the managers and some senior staff of the airline surveyed, and 372 completed questionnaires returned, out of which only 359 copies were found usable for the present study, resulting in an effective response rate of $89.75 \%$. . The data was analysed using descriptive statistics. The research instrument showed high reliability and validity. The Cronbach alpha reliability coefficient for market orientation variable (0.79) and performance measures $(0.86)$ exceed the value of 0.70 (suggesting adequate reliability, Cronbach (1947). The opinions of scholars of management of marketing confirmed the content validity of the measures used, while the pilot study result confirmed their predictive validity.

The findings from the research were presented below.

\section{Findings And Discussions}

In order to accomplish the purpose of the research study, the findings of the responses to the different issues are analysed in the form of tables (1-12) not shown here.

\section{Response to issue one - Customer emphasis.}

The respondents were asked about the customer emphasis as it is related to market orientation practices in their firms. The relevant questions in the questionnaire are 1,2,3, and 4.

From questions 1 and 2, majority of the respondents agreed that to a very high extent, (88\% and $82.4 \%$ respectively ) that their companies are committed to customer, and customer satisfaction is measured frequently and systematically. The third question which dwells on the encouragement of customers to make comment and complaint about the firm's business activities revealed that $42.7 \%$ of the respondents agreed to a very high extent, and $41.1 \%$ agreed to high extent with the statement. On question 4, $29 \%$ agreed to a very high extent, and $48.1 \%$ agreed to high extent that they do create customer values in their products and services.

Response to issue two-Intelligence generation .Respondents were asked about intelligence generation activities being used by their firms and the relevant questions in the questionnaire are 5,6,7, and 8 .

From the results, question 5 indicated that $44.9 \%$ agreed to very high extent, and $41.1 \%$ agreed to high extent, making a total of $86 \%$ of the respondents agreed that their airline do frequently collect data on their sector of business for use in planning their activities, while only few very of respondents from Question 6 agreed that they know their customer and their line of business activities to a large extent. Question 7 revealed that $78 \%$ of the respondents agreed to a very high and high extent that they do survey their customers once in a year, and while question 8 showed that $80 \%$ of the respondents agreed to a very high and high extent that their airline do examine the probable effect of the business environment on their customers.

Response to issue three - Intelligence dissemination. Respondents were asked about intelligence dissemination activities involved in by their airlines and relevant questions in the questionnaire are 9,10 , and 11. Question 9 showed that $50 \%$ of the respondents agreed that report on their customers as well as success or failure of the business operation is distributed to the entire department for effective use. $40 \%$ agreed to an average extent, $8.1 \%$ agreed to a low and very low extent, while $0.9 \%$ did not agree with the statement at all. Question 10 on distribution of customer satisfaction report to all members of staff across the entire department revealed that 50\% agreed with the very high and high extent statement, $40 \%$ agreed averagely, while the remaining respondents had a very low agreement with the statement. Results from question 11 also followed the same pattern with question 9 and $10,30.5 \%$ of the respondents agreed that their airline do circulate document that provides information on their customers competitors periodically, $26 \%$ agreed to an average extent, while the remaining $43.5 \%$ did not agree with the statement.

Response to issue four - Intelligence responsiveness / implementation was investigated using questions 12, $13,14,15$ and 16 of the questionnaire.

Question 12 revealed that $73.8 \%$ agreed to a very high and high extent with the statement which says that information obtained from the customers are used in improving the quality of services rendered by the firm, 20.\% agreed to an average extent, while the remaining 6.2\% agreed to below average. Question 13 shows that majority of the respondents agreed with the statement on giving rapid attention to the customers' complaint. On the response to the information from the customer, the analysis of response to question 14 disclosed that more than $90 \%$ of the respondents agreed to a very high and high extent that their airline always act and respond fast on information generated. Similarly, question 15 revealed that the respondents' airlines regularly analyze 
Impact of Market Orientation Practice on Business Performance of Airline Operators in Nigeria.

the activities and program of other airlines, so as to get more information about them and what they are up to at a particular point in time. Question 16 unveiled the level of interdepartmental coordination experienced by the respondents' airline when discussing relevant issues in the firm's line of business. Majority of the respondents which represents $85 \%$ agreed to a very good extent, while $136 \%$ agreed with the statement average and the remaining $1.4 \%$ very low extent.

\section{Response to issue five - Top management emphasis.}

Questions were asked about the emphasis of senior management on customer satisfaction.

Majority of the respondents to question 17 agreed to a very high and high extent $(95.2 \%)$ that top management of their companies always emphasis customer satisfaction. In similar manner, majority of the respondents to question 18 which bothers on intelligence generation relating to business activities agreed with the statement $81 \%$ to a very high and high extent. The analysis of question 19 shows that $84 \%$ of the respondents agreed to the fact that their top management always emphasis intelligence dissemination. Results from question 20 shows that $86 \%$ of the respondents agreed with the statement that senior management are strongly committed towards achieving company's mission or goals.

\section{Response to issue six - Top management risk aversion}

The respondents were asked about the risk aversion of top management of the firms.

The result of question 21 shows that $78 \%$ agreed to a very high and high extent that senior management believe that higher financial risks are worth taking for higher rewards. The result of question 22 also shows that majority of the respondents $78 \%$ agreed with the assertion that there is a rapid exchange of opinion amongst the departments on how to respond to the risk involve in their operation.

\section{Response to issue seven - Interdepartmental conflict.}

The respondents were asked about the interdepartmental conflict in their individual airline firms.

Question 23 shows that $89 \%$ agreed to a very high and high extent with the statement that greater interdepartmental conflict leads to lower customer emphasis, market information generation, dissemination and responsiveness. Analysis of Question 24 indicates that majority of the respondents agreed to a low extent with the statement on the compatibility of the objectives pursued by marketing department with those of the other departments.

\section{Response to issue eight - Interdepartmental connectedness}

The respondents were asked about the interdepartmental connectedness in their individual airline firms.

The analysis of question 25 shows that most of the respondents believed (90\%) to a very high or high extent that it is very easy to talk with anyone you need to regardless of rank or position. Question 26 shows that, $90 \%$ agreed to very high and high extent, that there is informal "hall talk" among individuals from different department.

\section{Response to issue nine - Formalisation.}

The respondents were asked about the Formalization of information in their individual airline.

Question 27 addresses the issue of formalization of information in the respondent airline. Majority of the respondents $(51 \%)$ agreed to a very high and high extent with the statement. However, they believed that too much formalization of information will affect the timeliness and quick resolve of customer complaint and comments. Question 28 showed that majority of the respondents $(73.3 \%)$ agreed to very high and high extent that they usually have the feeling that they are constantly monitored to see that they obey all the rules. Furthermore, $71 \%$ of the respondents agreed that they can make their own decision without checking with anyone else, and this might be attributed to the fact that employees are strictly made to follow the airline policies, or rules and regulations.; $21 \%$ had an average agreement; $8 \%$ agreed to low and very low extent with the statement as displayed in question 29.

Response to issue ten:- Centralisation. Questions were asked from respondents about the Centralization of information in their respective airlines. Question 30 shows that $32.4 \%$ of the respondents believed to very high or high extent that the greater the centralization of information the better the firms goals are reached; $67.6 \%$ of the respondents agreed to low and very low extent with the statement. Also, question 31 disclosed that majority of the respondents $98.6 \%$ agreed to very high and high extent that whatever decision they make that is suppose to have a superior approval, must have their boss approval.

Response to issues eleven -reward system. The respondents were asked about the reward system in their individual companies. Question 32 revealed that $67.6 \%$ agreed to very high and high extent, $28.2 \%$ agreed averagely, and $4.24 \%$ agreed to low and very low extent with the statement that their company relies on customer satisfaction and performance as a measure of rewarding managers. In question $33,7.7 \%$ of the respondents had a very low agreement with the statement that formal rewards are forthcoming to anyone who 
Impact of Market Orientation Practice on Business Performance of Airline Operators in Nigeria.

consistently provides good market intelligence. $42 \%$ of the respondents agreed with the statement to an average extent while $50.3 \%$ agreed to the statement of very high and high extent..

\section{Response to issues twelve - Overall market orientation practice.}

The overall market orientation practice in the study area was investigated using questions 34,35 , and 36 of the questionnaire. Question 34 revealed that majority of the respondents $96.3 \%$ agreed that their company defines quality of its business in terms of customer satisfaction. Furthermore, nearly all the respondents $98.2 \%$ agreed to a very high and high extent with the statement that their company is very sensitive to how its customers evaluate its business as displayed in question 35. In the same vein, majority of the respondents ( International Airlines $86 \%$ agreed to very high and high extent that they are totally satisfied with the business practices of their airlines, while only $6.8 \%$ of the local airline respondents agreed with the statement . More than $90 \%$ of the respondents show that they are not satisfied with the business practices and performance of their airlines). This may be due to lack of infrastructure, and constraint associated with the micro and macro environment which they operate.

\section{Test Of Research Hypotheses}

In this research work, hypotheses were formulated and regression was used in testing the hypotheses.

Table 13: Standardised Regression Coefficients

\begin{tabular}{|c|c|c|c|c|c|c|}
\hline \multirow[b]{2}{*}{ Independent variables } & & & & & \multirow[b]{2}{*}{$\mathrm{N}$} & \multirow[b]{2}{*}{$\mathrm{R}^{2}$} \\
\hline & $\begin{array}{l}\text { Customer } \\
\text { emphasis }\end{array}$ & $\begin{array}{l}\text { Intelligence } \\
\text { generation }\end{array}$ & $\begin{array}{l}\text { Intelligence } \\
\text { dissemination }\end{array}$ & Responsiveness & & \\
\hline $\begin{array}{l}\text { Top management emphasis on } \\
\text { Market orientation }\end{array}$ & 0.39 & $0.27 *$ & $0.29 *$ & $0.34 *$ & 359 & 0.49 \\
\hline Top management risk aversion & - & - & - & $-0.23 *$ & 359 & 0.36 \\
\hline Interdepartmental conflict & - & - & $0.23 *$ & $0.24 *$ & 359 & 0.44 \\
\hline Interdepartmental connectedness & - & - & $0.28 *$ & $0.37 *$ & 359 & 0.62 \\
\hline Formalization & - & $-0.1^{*}$ & -0.29 & $-0.29 *$ & 359 & 0.51 \\
\hline Centralization & - & & -0.19 & -0.27 & 359 & 0.33 \\
\hline Reward System & - & $0.46^{*}$ & 0.27 & $0.17 *$ & 359 & 0.67 \\
\hline
\end{tabular}

Source: Author's calculation (2016), $\mathrm{p}<0.05$

The table above gives the information about the antecedents of market orientation. From the regression analysis above, the level of emphasis placed on a market orientation by top management seems to influence customer emphasis (0.39); intelligence generation (0.27); intelligence dissemination (0.29) and responsiveness (0.34). Top management plays a critical role in tracking, generating, disseminating and responding to any market development. Some researchers observed that top management is required if individuals within the organization are to be encouraged, disseminate and respond to market intelligence (Levitt 1969; and Jaworski \& Kohli 1993). Narver and Slater (1995) opined that any firm that wants to be market-oriented must constantly deliver superior value to its customer through understanding of their needs and market trends. Therefore, it is very essential for top management to communicate to the employees the importance of being responsive to the customers and showing commitment, encouraging comments and complaints and take necessary action based on the information received. The study confirmed the earlier research finding of Jaworski and Kohli (1993) which opined that market orientation appears to be facilitated by the amount of emphasis top managers' place on customer satisfaction, intelligence generation, intelligence dissemination, and responsiveness/ implementation. Hence, the null hypothesis H1o is rejected, and the alternative hypothesis that the greater top management emphasis on customer intelligence generation, intelligence dissemination and intelligence responsiveness of the airline operators firms in Nigeria, the higher the market orientation practices will be accepted. It is observed that market orientation through proper intelligence generation and dissemination can help a firm in developing products, customer loyalty programs and services that are capable of providing a superior service to the customers by fulfilling their needs and the evolution of their preferences. The table above also shows that risk aversion of top managers does not have any influence on intelligence generation and dissemination but have negative effect on the responsiveness ( -0.23). This is in line with the findings of Jaworski and Kohli (1993) that "responding to market developments entail some amount of risks and that if top managers are unwilling to assume these risks, the organization is less likely to be responsive to the changing preferences of customers". H2o: The greater the top management risk aversion, the lower the market orientation practices - hypothesis $\mathrm{H} 2 \mathrm{O}$ is hereby accepted. Interdepartmental conflict appears to impede the intelligence dissemination $(-0.23)$ and responsiveness (-0.24). Inter-departmental conflict is detrimental to the implementation of market orientation. It has the potential to contribute to breakdowns in communication, secrecy and in-breed competition among the employees. Hence, hypothesis $\mathrm{H} 30$ that the greater the interdepartmental conflict, the lower the customer emphasis, market intelligence dissemination and responsiveness of the airline firms in Nigeria is hereby accepted. 
Impact of Market Orientation Practice on Business Performance of Airline Operators in Nigeria.

The finding also shows that Interdepartmental connectedness promotes market intelligence dissemination (0.28) and responsiveness (0.37). Connectedness facilitates adequate amount of intelligence to be disseminated and also allows for proper responsiveness. Connectedness across the entire department in the organization facilitates open flow of resources work and assistance across all the departments. Hence, the hypothesis $\mathrm{H} 4 \mathrm{o}$ is rejected, and the alternative hypothesis which state that the greater the interdepartmental connectedness, the higher the customer emphasis, intelligence generation, market intelligence dissemination and responsiveness of airline firms in Nigeria is accepted.

From the table, it shows that formalization of information is inversely related to intelligence generation ( -0.1), intelligence dissemination $(-0.29)$ and responsiveness $(-0.29)$. The implication of this is that formalization of information inhibits market orientation. Hence, H5o: The greater the formalization in decision making, the lower the intelligence dissemination, and responsiveness is hereby accepted.

Centralization too tends to impede the intelligence dissemination $(-0.19)$ and responsiveness $(-0.27)$, hence , hypothesis H6o: greater the centralization in decision making, the lower the market orientation is hereby accepted.

The type of measurement and reward systems adopted by the organization will determine the extent to which market orientation is adopted. Reward system enhance intelligence generation ( 0.46 ), intelligence dissemination ( 0.27) and responsiveness (0.17). Hence hypothesis H8o is hereby rejected, and the alternative hypothesis which state that : The greater the market orientation practices of airline firms in Nigeria, the higher the firm business performance (profitable market share, customer satisfaction, repeat customer, innovation, and sales growth, ) is hereby accepted. In the final analysis, market orientation seems to have a strong positive relationship with the overall business performance when judgmental measures such as customer satisfaction, growth of customer base, staff commitment and achievement of business performance goals are used.

\section{Concluding Comments,}

The research has investigated the market orientation practice of airline operators in Nigeria and how it contributes to the firms' performance. The major objective is to identify the market orientation components that influenced the performance of airline firms in Nigeria.

Findings from this research revealed that majority of the respondents scored the issues raised in the questionnaire positively. The study identified some components that are very crucial to the determinant of market orientation practice by airline operators in Nigeria. The study confirmed the earlier research finding of Jaworski and Kohli (1993) which opined that market orientation appears to be facilitated by the amount of emphasis top managers' place on customer satisfaction, intelligence generation, intelligence dissemination, and responsiveness/ implementation (HypothesisH1). It is observed that market orientation through proper intelligence generation and dissemination can help a firm in developing products and services that are capable of providing a superior service to the customers by fulfilling their needs and the evolution of their preferences.

The research also revealed that the level of risk aversion of top management as an antecedent of market orientation is very relevant and must be taken seriously by the airline operators in order to achieve the benefits of market orientation (Hypothesis H2). For example, the introduction of new product or product loyalty programs, or services is often risky because of probability of failure. But, when the top management is ready and willing to take a calculated risk and accept any failure that may arise from their action, the employees in the lower hierarchy of the organization will be encouraged to be committed and responsive to customer needs. Jaworski and Kohli (1993) also observed that when top management is not committed to taking risks and also not ready to accept failures, the lower level of employees may feel discouraged and less likely to be responsive to customers' need.

Interdepartmental conflict has been found to inhibit the process of market orientation (H3)), while interdepartmental connectedness plays a facilitative role in promoting market orientation practice in the study area (H4). Lack of cooperation in an organization can affect intelligence generation on product, service, competitors and the way the information is being disseminated and responded to. The negative relationship observed between interdepartmental conflict and market orientation has been observed by various researchers. The level of interconnectedness among employees in the surveyed airline firms in Nigeria which involves formal and informal contact within the employees in the organizations has been found to have significant effect on market orientation (H4). This finding is in line with the findings of Ruekert and Walker (1987) and Jaworski and Kohli (1993). Formalization and Centralization of decision making within the studied airline firms in Nigeria have been found to have a significant negative relationship with market orientation in accordance with the stated hypothesis (H5 \& H6). This shows that concentration of power of decision making at a single point in the organization may hinder the quick decision making and the manner in which employees respond to the market needs of the customer. The study of Jaworski and Kohli (1993) revealed that formalization and centralization do not appear to affect market orientation, but observed that their presence is a very crucial determinant of market orientation. . 
The role of reward system in entrenching market orientation practice is discovered to be a very important determinant in the sampled airline firms in Nigeria (H7). It was observed that if a firm reward system is based on how customer was treated; the employees are more likely to respond with all sense of urgency to customers' needs. The findings from the study revealed that there is a significant relationship between market orientation and overall business performance (H8) using subjective measures of performance such as customer satisfaction, staff commitment, innovation etc. Proper implementation of market orientation practice has been seen by many as a catalyst for increased customer satisfaction and enhanced service delivery. In conclusion, results from the study firmly suggest that market orientation practises generally affects airline operators firms performance to a reasonable extent in Nigeria. These results may be useful to both academics and business practitioners with interest in the Nigerian economy It is suggested that future research replicates this study in other developing economies, in order to enhance the understanding of the practical application of market orientation in such economies. Future research may also adopt a comparative perspective of effects of market orientation practices by conducting empirical studies on international airline operators and local airline operators in a developing economy like Nigeria.

\section{References}

[1] Bigne, E., Kuster, I. and Toran, F. (2003), 'Market orientation and Industrial sales force diverse measure instrument, journal of Business and Industrial Marketing, Vol.18, No. 1 pp $59-81$.

[2] Blackson c. and Stokes, D. (2002), 'Marketing practices in the UK small business sector' Marketing intelligence and planning, Vol.20, No .1, pp $49-61$.

[3] Cronbach, L.T. (1947): Test reliability: its meanings and determination, Psychometrical Vol. 12, No.1, pp 1-16

[4] Deng, S. AND Dart .J. (1994) 'measuring market orientation: a multi - factor, multi - item approach' Journal of Marketing management, Vol. 10, pp $42-725$.

[5] Deshpande, R, farley, J. U. and Webster, F. (1993),'corporate culture, customer orientation and innovationess', Journal of marketing, Vol. 57, pp 23 -37. Deshpande, R, (2001). Using marketing knowledge, Thousand Darks, sage.

[6] Ellis P. D. (2006). Market orientation and performance: A meta-analysis and cross national comparisons. Journal of Management Studies, 43, 1089-1097.

[7] Gray, B. Matear, S. Boshoff, C. and Mathesan, P. (1998), "Developing a better measure of market orientation", European journal of marketing, vol .32 Nos.9/8 pp 884-903.

[8] Groenroos, C (2000), service management and marketing-A customer Relationship Approach, Chichester, Jonh Willey and Son.

[9] Hult G. T. M., Ketchen J. D. J. (2000). Does market orientation matter? A test of the relationship between positional advantage and performance. Strategic Management Journal, 22, 899-906.

[10] Jaworski, B. J. \& Kohli, A. K. (1993). Market orientation: Antecedents and consequences.Journal of Marketing, 57 (July), $53-70$.

[11] Kohli, A.K., Jaworski, B. J. (1990), 'Marketing Orientation: The Construct, Research Proposition and Managerial Implication', Journal of Marketing, Vol.54, No. 2, pp 1-18

[12] Kohli, A.K., Jaworski, B. J. and Kuma, A.(1993),'MARKOR, A Measure Market Orientation, Journal of Marketing Research, Vol. 30, No 4, pp $467-78$.

[13] Kotler, P. (2002), Marketing Management, $11^{\text {th }}$ Edition, New Delhi, Prentice Hall.

[14] Lado, N. Maydean - Olivares, A and Rivera, J. (1998), 'Measuring Market Orientation in Several Populations - A Structural Equations Model', European Journal of Marketing, Vol.32, No. 1/2, pp 32 - 39.

[15] Lafferty, B. A. and Huit, T.M. (2001), 'A Synthesis of Contemporary Marketing Orientation Perspectives,' European Journal of Marketing, Vol. 35, No 1/2, pp $92-109$.

[16] Loing, A, Lewis, B. Fosal, G. and Hogg, G. (2002), 'Predicting a diverse future: Directions and Issues in the Marketing of Services: European Journal of Marketing, Vol. 36, No. 42, pp479 - 94 Maydeu - Olivares, A. AND Lado N. (2003), 'Marketing Orinetation and Business Economic Performance: A Mediated Mode,' International Journal of Service Industry Management, Vol. 14, No. 3 pp $284-309$.

[17] Narver, J.C. and Slater, S.F. (1990), 'The Effect of a Market Orientation on Business Profitability,' Journal of Marketing, Vol. 54, No. 4,pp $20-36$.

[18] Raaij E. M. V., Stoelhorst J. W. (2008). The implementation of a market orientation: A review and integration of the contributions to date. European Journal of Marketing, 42, 1265-1293.

[19] Ramayah T., Samat N., Lo M. C. (2011). Market orientation, service quality and organizational performance in service organizations in Malaysia. Asia-Pacific Journal of Business Administration, 3, 8-27.

[20] Ruekert R. W. (1992). Developing a market orientation: An organizational strategic perspective. International Journal of Research in Marketing, 9, 225-24

[21] Shapiro B. P. (1988). What the hell is market oriented? Harvard Business Review, 66(6), 119-125.

[22] Management, Vol. 14, No. 3 pp $284-309$.

[23] Slater, S. F. \& Narver J. C. (1990). Does competitive environment moderate the market orientation-performance relationship? Journal of Marketing, 58 (1), 46-55.

[24] Slater, S. F. \& Narver. J. C. (1994). Market orientation, customer value, and superior performance. Business Horizon, (37), pp. 2229.

[25] Slater, S. F. \& Narver. J. C. (1994). Does competitive environment moderate the market orientation- performance relationship? Journal of Marketing. Vol. 58. pp. 46-55.

[26] Tomaz, 1 L. (2005), 'Development of Market Orientation in a Services Context: An alternative model Proposal'

[27] Vargo, S. L. and Lusch, r. F. (2004),'Evolving to a New Dominant Logic for Marketing,' Journal of Marketing, Vol. 68, (January) pp $1-17$. 